\title{
Validity of the Monetary Model of the Exchange Rate: Empirical Evidence from Sri Lanka ${ }^{1}$
}

\author{
Sujeetha Jegajeevan
}

\begin{abstract}
This paper studied the behaviour of the US dollar vis-à-vis the Sri Lankan rupee exchange rate in order to check the empirical validity of the flexible price monetary model of exchange rate. Data from January 2001 to March 2011 has been studied by employing the Johansen multivariate cointegration test and the Vector Error Correction Model (VEC) as the key techniques. A long-term cointegrating relationship between the nominal exchange rate and variables of monetary model has been found. The error correction term is quite large and significant indicating that short-term deviation from long-term equilibrium is restored within a year. However, regardless of the existence of a long-term relationship found between variables of the monetary model and exchange rate, the evidence is not strong enough to support the validity of the monetary model. This is mainly because of statistically insignificant domestic money supply and incorrect sign reported for foreign money supply. Improper evidences found on key variables of the model led to serious doubt about the ability of the flexible price monetary model in explaining exchange rate movements of US dollarSri Lankan rupee in the free floating exchange rate regime.
\end{abstract}

1 The author is thankful to her supervisor Dr. Gianluigi Vernasca for his guidance and support throughout this study and the anonymous referee for his valuable comments and corrections that helped to improve the quality of this paper. 


\section{Introduction}

Understanding and predicting movements of exchange rates have been essential tasks for traders as well as policymakers from the time the rates were allowed to float. Policy makers want to ensure that the exchange rate is moving according to economic fundamentals and does not fluctuate exceptionally, which is harmful not only to the foreign exchange market but also to the economy as a whole. The main objective of this study is to empirically assess the long-term relationship between the US dollar-Sri Lankan rupee exchange rate and economic variables of the flexible price monetary model of exchange rate and their short-term dynamics to determine whether exchange rate movements are in line with economic fundamentals. Though there is ample research on modelling exchange rate for advanced countries, studies based on emerging countries are limited to a few recent studies. This study is the first attempt, to the knowledge of the author, to test the validity of the monetary model of exchange rate for Sri Lanka. This paper contributes to the literature by adding empirical evidence on the validity of the monetary model from a small open economy that did not receive much attention in the literature in the past. Price stability being one of the key objectives of the Central Bank of Sri Lanka, exchange rate management and the monetary policy are closely related, even though exchange rate is not explicitly targeted. Since Sri Lanka is a small open economy adopting the monetary targeting framework, evidence about the long-term relationship between the exchange rate and monetary fundamentals is very helpful for the policy makers. This paper focuses on studying the validity of the flexible price monetary model during the free floating exchange rate regime to answer the following three main research questions.

1. Is there a long-term relationship between exchange rate and variables of the monetary model?

2. If there is any disturbance to the long-term relationship, how long will it take to revert to the long-term equilibrium level?

3. Can variables of the monetary models be used to predict movements of exchange rate in the long-run?

The study is based on monthly data from January 2001 to March 2011. Nominal exchange rate, money supply, income and interest rates of Sri Lanka and the USA are selected as the key variables of the model. The long-term relationship among these variables is studied by employing Johansen multi-variate cointegration analysis, while short term dynamics are studied based on the Vector Error Correction Model (VEC). Further, monetary restrictions imposed on the restricted flexible price model in theory are also tested to determine the empirical validity of such restrictions. 
The rest of the paper is organized into four more sections. Section 2 provides a brief overview of exchange rate regimes in Sri Lanka, a review of theoretical underpinning and empirical evidence. Section 3 briefly describes the data and methodology, while the main data analysis and presentation of results are presented in section 4. Finally, the summary of conclusions of the analysis and limitations of this study and further extensions are discussed in the final section.

\section{Related Theory and Empirical Evidences}

\subsection{Overview of Exchange rate Regimes in Sri Lanka}

Sri Lanka's foreign exchange rate policy has evolved according to different regimes starting from fixed exchange rate at the time of independence in 1948. In 1950 with the establishment of the Central Bank of Sri Lanka, the value of the rupee was fixed against gold. In 1971, with the suspension of convertibility of US dollar for gold, the Sri Lankan rupee was linked to US dollars and it was later linked to a basket of currencies of countries with which Sri Lanka had important trading linkages. In 1977, the managed floating regime was introduced and the US dollar became the intervention currency. The Central Bank announced it's buying and selling rates of US dollar for its transactions with commercial banks, while commercial banks were allowed to quote their buying and selling rates for currencies within the specified margins. The margin between the Central Bank's buying and selling rates were adjusted from time-to-time. In January 2001, foreign exchange transactions were liberalized by allowing commercial banks to determine the exchange rate freely with the objective of stabilizing the value of the rupee. The Central Bank no longer buys or sells foreign exchange at pre-announced rates, but monitors the movements of the exchange rate in the market, reserving the right to intervene in the market when there is high volatility in the short-term. It intervenes in the market by filling in temporary shortfalls in supply and demand that could otherwise result in unwarranted excessive fluctuations in exchange rates. Thus, Sri Lanka experienced a gradual transformation from a fixed exchange rate to a freely floating exchange rate over a half century. Overall, the US dollar-Sri Lankan rupee exchange rate has depreciated continuously, ignoring small appreciations experienced from time-to-time. For instance, by 1977 the exchange rate was around Rs.16 per US dollar. It depreciated to around Rs. 90 per US dollar in 2001 at the time of moving to free floating and hovered at around Rs. 110 per US dollar by 2011. The US dollar has been a major currency for international transactions throughout the past and countries to do so in the present. 


\subsection{Monetary Models of Exchange Rate and Empirical Evidences}

A number of structural models are developed in the literature of international finance to model exchange rate behavior. Before the 1970s, many countries adopted a fixed exchange rate regime and fixed price assumption based model, i.e., the purchasing power parity model (PPP), was considered as the most suitable model to study exchange rate behaviour. However with the transformation to floating exchange rate regimes in major advanced countries, since the 1970s monetary based models became popular in modelling long-term exchange rate behaviour. Following the liberalization of current and capital accounts of balance of payment and developments of exchange rate markets, several other variables such as volatility of capital flows, forward premium, government interventions and micro level dynamics in the exchange rate market became increasingly important in the determination of exchange rate behaviour in the short-term (Dua and Ranjan, 2011).

The PPP model states that prices are equalized by arbitrage forces at home and overseas when measured by a single currency. There could be a short-term deviation from PPP model, but in the long-term the exchange rate converges to the equilibrium level of the PPP. The PPP model was proved to be successful in modelling long-term exchange rate behaviour in the early literature.

In the monetary model, money supply in both domestic and foreign countries as opposed to money demand function determines the exchange rate. Monetary models are built on the basis of the PPP model. This model was built based on four main building blocks; continuous PPP, uncovered interest parity, stability of money demand function and exogeneity of money and real income. Thus the assumptions of these building blocks are applicable to the monetary model as well. This model has two main classifications known as flexible price and sticky-price models. The flexible price model (originally developed by Frenkel, 1976) is based on the assumption that prices are perfectly flexible and therefore any increase (decrease) in domestic money supply should increase (decrease) the domestic price level and as a result domestic currency will depreciate (appreciate) discretely to equalize prices in two countries. An important implication of this model is that PPP holds both in short-term and long-term. This is highly criticized by the pioneers of sticky price model.

The sticky price model was developed by Dornbusch (1976) by relaxing the assumption of short-term PPP while holding the long-term PPP assumption. It considers price rigidities in an economy in modelling exchange rate. Therefore, as noted by Moosa (2000) it is considered a 'hybrid model' in the sense that it incorporates the Keynesian property of fixed prices in the short-term and the classical property of flexible prices in the long-term. In this model domestic interest rate changes relative to foreign interest 
rate to equate the money market for a change in money supply relative to demand for money in the absence of a corresponding fall in price level. In the sticky price model PPP holds only in the long-run and an increase in domestic money supply does not depreciate the exchange rate proportionally in the short-run. Because of this, an increase in money supply leads to a fall in domestic interest rate and resulting capital outflow, instead of proportional depreciation in the exchange rate. Such an outflow of capital will result in the exchange rate overshooting above its equilibrium level in the short-term. The long run solution for the exchange rate in the sticky-price model is equal to the flexible-price model, but the sluggish adjustment of prices causes temporary overshooting of the exchange rate compared to the long run equilibrium (Schroder \& Dornau, 1999). Empirically, the sign and the significance of the coefficients of the interest rates and the long term inflation expectations are used to differentiate the flexible-price and the sticky price models. The basic structural models and models with different modifications are employed empirically by many researchers to model exchange rate behaviour for different countries and to forecast at different time spans. The empirical performance of the monetary models is discussed in the following section.

Empirical evidence over the last four decades on the applicability of monetary models to model exchange rate behaviour is mixed. Schroder and Dornau (1999) noted that monetary models were the centre of interest in exchange rate theory in the seventies and early eighties. Earlier research covering the 1970s for industrial countries is supportive of the monetary approach to exchange rate [see Frenkel (1976), Bilson (1978) and Dornbusch (1976)]. It has been observed that the in-sample performance of the monetary models were favourable in the years immediately following the breakdown of the Bretton Woods system and it collapsed in the 1980s (Dua and Ranjan, 2011).

Following the influential work of Meese and Rogoff (1983), who concluded that naïve random-walk model outperform out-sample forecast performance of any monetary model, the empirical interest in the monetary models started to fade. While some researchers were concentrating on different models, some researchers attempted to validate the monetary model by extending it with some variations and by applying new statistical and econometric techniques. Buiter and Miller (1981, cited in Dua and Ranjan 2011) extended the sticky price model by including trend inflation, which was proved to be successful in a few other later studies. Hooper and Morton (1982) extended the sticky price model by including changes in the long-run real exchange rate that is expected to be correlated with unanticipated shocks to the trade balance. The recent studies attempted to include market based variables such as transaction volumes or order flows, forward premia, capital flows, volatility in capital flows and central bank intervention that influence short term volatility of exchange rate. 
Several reasons have been highlighted for the failure of the monetary approach in modelling exchange rate behaviour. Meese (1990, cited in Dua and Ranjan, 2011) attributed the failure of the monetary models to their underlying relationship with PPP, instability in the money demand function and irrational expectations of agents. Abas and Yusof (2009) further added quoting Boughton (1988), Mac Donald (1988) and MacDonald and Taylor (1992) that the constraints imposed on relative money, income and interest rates, exogeneity of money supply, uncovered interest parity and inappropriate application of econometric tools are the causes of the failure of these models. Meredith (2003) stated that the exogeneity of money supply is no longer valid in the current financial system and monetary policy approaches of the central banks, since money supply is endogenously determined with other macro variables. Flood and Rose (1995, cited in Dua and Ranjan, 2011) stresses a valid point that while exchange rate exhibit substantial volatility, the economic fundamentals do not show such volatility in the short-term. So, exchange rates based only on economic fundamentals will not be adequate in explaining the exchange rate behaviour in the short-term. Sarno and Valente (2008) attributed weak out-sample performance of exchange rate models to poor performance of model selection criteria, rather than lack of information contents in fundamental. They further added that model selection becomes more difficult due to frequent shifts in the set of fundamentals driving exchange rate, which is a result of shift in market expectations over time. Further, exchange rate movements are dependent on speculative forces, rational and or irrational expectations of market players in the short-term, which make exchange rate relatively more volatile than the other macro variables in the short time span. Another explanation for this failure is that fundamental models are based on the current values of macro variables, but in practice the market responds to various information and expectations about fundamentals. It may not be a surprise if the models with current values fail to track actual movements of the exchange rate.

Regardless of all these criticisms, one cannot completely neglect evidence in favour of fundamental models, especially in the medium term and long-term. Fundamental economic models with few variations have shown evidence of good fit to the data and produce reasonably good forecast for certain currencies in the mid to long-term. Though in a short horizon of one to three years monetary fundamentals do not help much to predict the exchange rate, the predictive power is stronger for some currencies when the time span is widened to four to five years as summarized by Dua and Ranjan (2011), based on empirical literature. Meredith (2003) quoted that limited research in the 1990s such as MacDonald and Taylor (1994), Mark (1995), Chen and Mark (1995) and Mark and Choi (1997) have found the predictive power of monetary models in the medium term. Mark (1995) has found that both in-sample and out-sample forecast performance 
of monetary models increased when the forecast horizon was strengthened and forecast error was half of the error generated by the random walk forecast. Several other studies are quoted in Liew et al. (2009) that have found evidences on long-term relationships between exchange rate and the variables of monetary models in the advanced countries, using the cointegration techniques of Johansen (1988, 1989), Johansen and Juselius (1990) and the Engel Granger approaches (see MacDonald and Taylor (1991) and Choudhry and Lawler (1997).

Moreover, many recent studies based on emerging countries are supportive of the long-term validity of monetary models. While Abas and Yusof (2009), Liew et al. (2009) and Chin et al. (2007) have proved the long-term validity of the monetary models in Malaysia, Thailand and the Philippines, respectively, Dua and Ranjan (2011) have shown that different variations of the monetary model forecasts over-perform the random walk model in India.

Engel et al. (2007) stress a peculiar and interesting argument about the approaches to evaluate exchange rate models. Contrary to the consensus of empirical literature they highly criticized the central criterion of judging the models by comparing them with the random walk model. Good models do not necessarily out-perform the random walk models, since many such models indeed imply that exchange rates are nearly a random walk and beating the random-walk model forecast is too strong criterion in accepting the model.

To sum up, the empirical evidence of monetary models based on individual time series are mixed. The extensions to validity of these models in the recent past consider three different approaches such as use of panel data, increase the time span to more than a decade and application of non-linear models. There are ample research attempts and evidence on the validity of the monetary models in advanced countries. But, evidences from emerging countries is limited to a little recent research and most of them have proved the long-term validity of monetary models in these countries. The long-term relationship between monetary model based variables and exchange rate has been well accepted both in theoretical and empirical literature, though short-term validity was challenged. Finally, evidence that the models do not out-perform the random walk model alone cannot be used to reject the validity of monetary models. Table 2.1 summarizes the main features of some empirical works, which are more relevant to this study. 
Table 2.1 : Summary of Empirical Evidences

\begin{tabular}{|c|c|c|c|}
\hline Authors & Scope & Methodology & Key Findings \\
\hline $\begin{array}{l}\text { Meese and } \\
\text { Rogoff (1983) }\end{array}$ & $\begin{array}{l}\text { 1973- } 1981-\text { monthly } \\
\text { data for US dollar and } \\
\text { UK pound }\end{array}$ & $\begin{array}{l}\text { Univariate time } \\
\text { series model, } \\
\text { flexible price } \\
\text { and sticky } \\
\text { price monetary } \\
\text { models using } \\
\text { unconstraint VAR }\end{array}$ & $\begin{array}{l}\text { Random walk model } \\
\text { outperforms the time series } \\
\text { and structural models in } \\
\text { short-term }\end{array}$ \\
\hline Mark (1995) & $\begin{array}{l}\text { 1973-1991 - quarterly } \\
\text { data for Canadian } \\
\text { dollar, deutsche mark, } \\
\text { Swiss franc and yen } \\
\text { against US dollar }\end{array}$ & Monetary models & $\begin{array}{l}\text { Out-sample point predictions } \\
\text { of the models outperform } \\
\text { drift-less random walk } \\
\text { forecast when forecast } \\
\text { horizon is longer. }\end{array}$ \\
\hline $\begin{array}{l}\text { MacDonald } \\
\text { and Taylor } \\
\text { (1991) }\end{array}$ & $\begin{array}{l}\text { 1976-1990 - monthly } \\
\text { data for currencies of } \\
\text { German, Japan and } \\
\text { UK against US dollar }\end{array}$ & $\begin{array}{l}\text { Monetary model } \\
\text { using multivariate } \\
\text { cointergration } \\
\text { technique }\end{array}$ & $\begin{array}{l}\text { Unrestricted monetary } \\
\text { model is a valid framework } \\
\text { for analyzing the long run } \\
\text { exchange rate. Further, } \\
\text { the proportionality of the } \\
\text { exchange rate to relative } \\
\text { money supplies is valid for } \\
\text { the German mark }\end{array}$ \\
\hline Groen (2002) & $\begin{array}{l}\text { 1975-2000 - quarterly } \\
\text { data for euro against } \\
\text { the currencies of } \\
\text { Canada, Japan and US }\end{array}$ & $\begin{array}{l}\text { Monetary models } \\
\text { using panel VEC } \\
\text { techniques }\end{array}$ & $\begin{array}{l}\text { Forecasting performance } \\
\text { of monetary model based } \\
\text { common long-run model is } \\
\text { superior to random walk and } \\
\text { standard VAR model based } \\
\text { forecasts. }\end{array}$ \\
\hline $\begin{array}{l}\text { Meredith } \\
\text { (2003) }\end{array}$ & $\begin{array}{l}\text { Mainly 1981- } \\
2002 \text { - monthly } \\
\text { and annual data for } \\
\text { G-7 currencies and } \\
\text { currencies of selected } \\
\text { small industrial and } \\
\text { emerging countries }\end{array}$ & $\begin{array}{l}\text { PPP, uncovered } \\
\text { interest rate parity } \\
\text { (UIP), monetary } \\
\text { model }\end{array}$ & $\begin{array}{l}\text { Though PPP and monetary } \\
\text { model are favourable in } \\
\text { in-sample forecast, when } \\
\text { adjusted for finite-sample } \\
\text { estimation bias they lose their } \\
\text { predictability in medium } \\
\text { term. }\end{array}$ \\
\hline Civcir (2003) & $\begin{array}{l}\text { 1986-2000 - monthly } \\
\text { data for Turkish lira - } \\
\text { US dollar }\end{array}$ & $\begin{array}{l}\text { Different versions } \\
\text { of monetary } \\
\text { models }\end{array}$ & $\begin{array}{l}\text { Exchange rate is cointegrated } \\
\text { with long-run fundamentals } \\
\text { and equilibrium correcting } \\
\text { monetary models significantly } \\
\text { outperform random walk. }\end{array}$ \\
\hline
\end{tabular}




\begin{tabular}{|c|c|c|c|}
\hline Authors & Scope & Methodology & Key Findings \\
\hline $\begin{array}{l}\text { Islam \& } \\
\text { Hasan (2006) }\end{array}$ & $\begin{array}{l}\text { 1974-2003 - quarterly } \\
\text { data for yen against } \\
\text { US dollar }\end{array}$ & $\begin{array}{l}\text { Monetary } \\
\text { model using } \\
\text { cointegration and } \\
\text { VEC technique }\end{array}$ & $\begin{array}{l}\text { There is long-term causation } \\
\text { flowing from monetary } \\
\text { variables to exchange rate } \\
\text { and forecast performance of } \\
\text { monetary model outperforms } \\
\text { random walk model }\end{array}$ \\
\hline $\begin{array}{l}\text { Lam et al. } \\
\text { (2008) }\end{array}$ & $\begin{array}{l}\text { 1973-2007 - quarterly } \\
\text { data for euro, UK } \\
\text { pounds and yen } \\
\text { against US dollar }\end{array}$ & $\begin{array}{l}\text { PPP, UIP, sticky } \\
\text { price monetary } \\
\text { model, a model } \\
\text { based on } \\
\text { Bayesian model } \\
\text { average and a } \\
\text { combined model } \\
\text { of all above } \\
\text { models }\end{array}$ & $\begin{array}{l}\text { The combined model } \\
\text { outperforms the random walk } \\
\text { model and yields better result } \\
\text { than any of the single model. }\end{array}$ \\
\hline $\begin{array}{l}\text { Abas \& Yusof } \\
\text { (2009) }\end{array}$ & $\begin{array}{l}\text { 1980-2007 - quarterly } \\
\text { data for ringgit and } \\
\text { yen against US dollar }\end{array}$ & $\begin{array}{l}\text { Flexible price } \\
\text { monetary } \\
\text { model using } \\
\text { cointegration and } \\
\text { error correction }\end{array}$ & $\begin{array}{l}\text { Strong evidences of } \\
\text { long-term relationship } \\
\text { between exchange rate and } \\
\text { monetary fundamentals in the } \\
\text { selected countries. }\end{array}$ \\
\hline $\begin{array}{l}\text { Liew et al. } \\
\text { (2009) }\end{array}$ & $\begin{array}{l}\text { 1977-2006 - monthly } \\
\text { data for Thailand baht } \\
\text { against yen }\end{array}$ & $\begin{array}{l}\text { Flexible price } \\
\text { monetary } \\
\text { model using } \\
\text { cointegration and } \\
\text { VECM }\end{array}$ & $\begin{array}{l}\text { There is long-term } \\
\text { relationship between } \\
\text { exchange rate and monetary } \\
\text { fundamentals and monetary } \\
\text { models works well in small } \\
\text { and open emerging economy } \\
\text { (Thailand) }\end{array}$ \\
\hline $\begin{array}{l}\text { Dua and } \\
\text { Ranjan (2011) }\end{array}$ & $\begin{array}{l}\text { 1996-2006 - monthly } \\
\text { data for India rupee } \\
\text { against dollar }\end{array}$ & $\begin{array}{l}\text { Monetary model } \\
\text { and various } \\
\text { extensions of it } \\
\text { using VAR and } \\
\text { BVAR }\end{array}$ & $\begin{array}{l}\text { Monetary model with } \\
\text { extensions (including central } \\
\text { bank interventions, capital } \\
\text { flows and forward premia) } \\
\text { outperforms random walk } \\
\text { model and BVAR model } \\
\text { outperforms corresponding } \\
\text { VAR model. }\end{array}$ \\
\hline
\end{tabular}




\section{Data and the Model}

\subsection{Data}

Data used in this paper consists of secondary data with respect to Sri Lanka and USA. Since the free floating exchange rate regime was introduced in Sri Lanka only recently in 2001, quarterly series could not be selected for this research as opposed to many other similar studies. Instead, data on monthly frequency for the period from January 2001 to March 2011 is considered. Data related to Sri Lanka is collected from a database available at the Central Bank of Sri Lanka, while that of United States is gathered mainly from International Finance Statistics (IFS) of the IMF and statistical publications of the Federal Reserve Bank. Key macroeconomic variables involved in the money demand function, such as money supply, interest rate and income have been chosen to develop the flexible price monetary model of exchange rate. Since GDP estimates are available only quarterly, the industrial production index has been chosen as a proxy for income. In addition to these fundamental variables, it was attempted to extend the model by including some additional variables such as trade balance, current account balance, trade volumes, central bank interventions and forward premia. However, due to the lack of availability of data for the selected period and frequency only central bank intervention has been chosen as the additional variable to extend the basic version of the monetary model. Further, due to the nature of the economy and the status of the foreign exchange market, central bank intervention plays an important role in determining the exchange rate behaviour for Sri Lanka rather than any other variables mentioned above. A detailed description of data is included in Appendix Table 1A. E-views 7.0 has been used for econometric analysis of the model.

\subsection{Theoretical Model}

The empirical evidences shows that monetary models work well in the long-run, but lose their predictability in the short-run to naïve random walk forecasts, as the volatility of exchange rates substantially exceeds that of the volatility of macroeconomic fundamentals. This paper is based on the flexible price monetary model in the long-term. Monetary models are based on a few assumptions such as PPP, uncovered interest parity, a stable money demand function and exogeneity of money and real income with respect to exchange rate (Meredith, 2003). The Vvalidity of the flexible price monetary model in the Sri Lankan perspective is tested using the cointegration and Vector Error Correction (VEC) framework.

A brief note on the derivation of the model is discussed in this part. The derivation of the model basically follows the ideas of Moosa (2000) and Neely and Sarno (2002). 
Flexible The flexible price model assumes that PPP holds continuously in short-term and long-term and any change in the money supply will lead to a proportional change in exchange rate through changing the domestic price level. The simplest version of the monetary model is derived by assuming the following stable money demand function.

$$
\begin{aligned}
& m_{h}=p_{h}+k_{h} y_{h}-\lambda_{h} i_{h} \\
& m_{f}=p_{f}+k_{f} y_{f}-\lambda_{f} i_{f}
\end{aligned}
$$

Variables $m, p, y$ and $i$ denote the log-level money supply, the price level, income and the level of interest rates, respectively, and subscripts $\mathrm{h}$ and $\mathrm{f}$ refers to home and foreign. The labels $k$ and $\lambda$ are constants. According to the flexible price model PPP holds, so that the log nominal exchange rate between home and foreign will be given by the following equation.

$$
e=p_{h}-p_{f}
$$

where, $e$ is the log nominal bilateral exchange rate.

Solving equations 3.1 and 3.2 for $p_{h}$ and $p_{f}$, respectively, and replacing in 3.3 yields the following equation.

$$
e=\left(m_{h}-m_{f}\right)-k\left(y_{h}-y_{f}\right)+\lambda\left(i_{h}-i_{f}\right)
$$

For simplicity, the assumption of symmetry and proportionality has been imposed in deriving equation 3.4, which represents the restricted form of the flexible price model. The symmetricy assumption implies the equality of income elasticity and interest semi elasticity of the demand for money in home and foreign. According to the assumption of proportionality, a rise in the domestic money supply leads to a proportional rise in the price level via the quantity theory of money and to a proportional depreciation of domestic currency via the purchasing power parity and vice versa (Liew et. al., 2009) .

The testable form of equation 3.4 is as follows.

$$
e=\beta_{1} m_{h}-\beta_{2} m_{f}-\beta_{3} y_{h}-\beta_{4} y_{f}+\beta_{5} i_{h}-\beta_{6} i_{f}
$$

Equation 3.5 is the unrestricted flexible price monetary model. In the literature, tests on monetary restrictions are usually performed (MacDonald and Taylor, 1991). The proportionality between money supply and nominal exchange rate can be tested by the null hypothesis $H_{1}: \beta_{1}=1$ and $H_{2}: \beta_{2}=1$. The symmetry can be tested by the null hypotheses $H_{3}: \beta_{1}=-\beta_{2}, H_{4}: \beta_{3}=-\beta_{4}$ and $H_{5}: \beta_{5}=-\beta_{6}$. 
Since the nominal exchange rate is expressed in terms of domestic currency per unit of foreign currency, a positive relationship between domestic money supply and nominal exchange rate and a negative relationship between foreign money supply and exchange rate are expected. Similarly, an increase in domestic income through an increase in demand for money tends to appreciate the exchange rate and therefore a negative relationship is expected and vice versa. According to the assumption of flexible price model the changes in interest rate reflects the changes in expected inflation. Thus, when the domestic nominal interest rate increases domestic currency is expected to lose its value through inflation ( Abas and Yusof (2009). The domestic interest rate is expected to have the same effect as the domestic money supply, and therefore a positive relationship is expected with the exchange rate. An increase in foreign interest rate, in contrast, tends to appreciate the local currency.

The beta coefficients are expected to have the following signs in the estimates.

$$
\begin{aligned}
& \beta_{1}>0, \beta_{2}<0 \\
& \beta_{3}<0, \beta_{4}<0 \text { and } \\
& \beta_{5}>0, \beta_{6}<0
\end{aligned}
$$

Empirical evidences shows only a weaker correlation between exchange rate and fundamental macroeconomic variables in the short-term. The movement of exchange rate in the short-term, like any other asset price, is largely dependent on the expectation of market players, which is not captured by the standard exchange rate models. Dua and Ranjan (2011) have highlighted transaction volumes or order flows, forward premia, capital flows, volatility in capital flows and central bank intervention as a few useful variables in the short to medium-term forecasts. Due to the lack of availability of data and relevance to the Sri Lankan context, only central bank intervention is used to extend the basic version of the monetary model. Accordingly, the extended model can be expressed as follows.

$$
e=\beta_{1} m_{h}-\beta_{2} m_{f}-\beta_{3} y_{h}+\beta_{4} y_{f}+\beta_{5} i_{h}-\beta_{6} i_{f}+\beta_{7} c b i n t
$$

Central bank intervention is the net purchases of foreign exchange by the central bank in the foreign exchange market. Central bank intervenes in the market to control excess fluctuations in the market. It buys foreign exchange when there is an abnormally high inflow of foreign exchange, to avoid high appreciation of exchange rate and vice versa,. So that, net purchases will reduce the level of appreciation and therefore, a positive relationship between central bank intervention and exchange rate is expected $\left(\beta_{7}>0\right)$. 


\subsection{Methodology}

The main analysis of this paper is based on multivariate cointegration analysis and vector error correction modeling. The monetary model is tested using a VAR based cointegration technique developed by Johansen (1995). The cointegration analysis requires all the variables to be integrated of the same order, generally I(1). Therefore, before running a cointegration test all the variables are tested for the presence of unit root using the Augmented Dickey Fuller (ADF) test. Neely and Sarno (2002) explains the need to test for stationary as follows. A stationary series tend to return to its expected level (mean reverting) when it departs from it. But, if the series is not mean reverting and infinitely persistent that series is nonstationary. A regression is meaningful only if the equation can be written so that the error is $\mathrm{I}(0)$. If error is $\mathrm{I}(1)$ the estimates of coefficients will be inconsistent. This requires either all variables in the equation to be $\mathrm{I}(0)$ or some combination of them is to be $\mathrm{I}(0)$. The cointegration test is a test to check whether there is a linear combination of $\mathrm{I}(1)$ variables that is $\mathrm{I}(0)$.

Generally, most of the macroeconomic variables are not stationary. Thus, a regression involving these variables will be spurious, though the goodness-of-fit of the model is high and the variables are statistically significant. Thus, cointegration analysis is carried out to check for the presence of a long-term relationship among the selected macroeconomic variables. The presence of cointegration relation implies that the linear combination of nonstationary variables is stationary and there is a corresponding error correction representation which shows the short-term deviation from the long run relationship.

Another way to confirm the existence of a cointegrating relation is the test for causality. If two variables are cointegrated causality in the Granger sense must exist in at least one direction (Granger, 1988, cited in Dua and Ranjan 2011). VEC Granger Causality/ Block Exogeneity Wald test is employed to check whether there is causation running from the variables of the monetary model to the exchange rate or from the exchange rate to such variables.

VEC estimates help to study short-term dynamics more than the long-term relations established by the cointegration test. The VEC has cointegration relations built into the specification that limits long-run movements of the variables in the model to converge to their cointegrating relationships while allowing for short-run adjustment dynamics. The cointegration term, which is also known as the error correction term, shows how deviation from long-run equilibrium is corrected gradually through a series of partial short-run adjustments. Generally a larger error correction term $(\alpha)$ means convergence to equilibrium level at a faster rate. 
More than finding long-term validity of the monetary model and its short-term dynamics, validity of the assumptions of monetary restrictions of the restricted version of the monetary model are also tested to check the validity of the chosen unrestricted model. Checking forecast performance of the model is out of the scope of this study, mainly because of the restricted sample period.

\section{Empirical Results}

\subsection{Unit Root Test}

In simple terms, a time series is stationary if it's mean and variance do not vary systematically over time. In a stationary time series the mean and variance (at various lags) remain the same no matter what point we measure them. Therefore, time series will tend to return to its mean and fluctuations around this mean will have broadly constant amplitude. The Unit root test is carried out to test whether a series is level stationary [I (0)] or first difference stationary [I (1)]. The Augmented Dickey-Fuller test (ADF) has been employed in this research. If the test statistic value (i.e., estimated value) is smaller than the critical values at 1 per cent, 5 per cent or 10 per cent significance level, then the null hypothesis is accepted. The null hypothesis is that the series has a unit root, or the series is not stationary at its level.

Table 4.1: Outcome of Unit Root Test

\begin{tabular}{|c|c|c|c|}
\hline \multirow{2}{*}{ Variables } & \multicolumn{3}{|c|}{ ADF Test } \\
\hline & At levels & Ist Difference & Result \\
\hline Inexr & -2.62 & -3.88 & $\mathrm{I}(1)$ at $5 \%$ \\
\hline slmoney & -2.26 & -4.09 & $\mathrm{I}(1)$ at $1 \%$ \\
\hline slind_pro & -2.15 & -4.19 & $\mathrm{I}(1)$ at $1 \%$ \\
\hline slint & -1.55 & -2.83 & $\mathrm{I}(1)$ at $10 \%$ \\
\hline usmoney & -2.00 & -3.53 & $\mathrm{I}(1)$ at $5 \%$ \\
\hline usind_pro & -2.10 & -3.46 & $\mathrm{I}(1)$ at $5 \%$ \\
\hline usint & -2.35 & -2.71 & $\mathrm{I}(1)$ at $10 \%$ \\
\hline cbint & -5.45 & & $\mathrm{I}(0)$ variable \\
\hline \multirow{4}{*}{ Test critical values: } & & Intercept & Intercept \& Trend \\
\hline & $1 \%$ level & -3.49 & -4.03 \\
\hline & $5 \%$ level & -2.89 & -3.45 \\
\hline & $10 \%$ level & -2.58 & -3.15 \\
\hline
\end{tabular}

Note: Variables other than slint, usint, usind-pro and cbint have shown a clear trend. So that intercept and trend are included in the test equation for these variables.

Source: Author's Estimates 
Table 4.1 reports the outcome of the ADF test. Different lag levels are used for different series that maximizes maximize the Akaike Information Criteria (AIC). Accordingly all the variables, except central bank intervention, are nonstationary at their levels or in other words all these variables are I (1) variables.

\subsection{Cointegration Analysis and Vector Error Correction Estimates}

Having established that the key variables of the model are I (1), Johansen (1995) multivariable cointegration analysis is carried out to check whether these I (1) variables are linearly cointegrated in the long-run. Central bank intervention, which is found to be $\mathrm{I}(0)$, is used as an exogenous variable in the cointegration test. Also a dummy variable is included as an exogenous variable mainly to capture the impact of the financial crisis on the US industrial production index, immediately following the crisis.

A lag length of 2 has been chosen in first difference terms (i.e., lag of 3 in levels) initially for correlation and vector error correction analysis that maximizes the AIC criterion. At this lag length the autocorrelation LM test rejects the null hypothesis of the presence of serial correlation in the model. It confirms that the chosen lag level is optimum and the model is not mis-specified. Deterministic trend specification of the cointegration test assumes that level data have linear trends but cointegrating equations have only intercepts. Critical values for the test are based on MacKinnon-Haug- Michelis (1999) p-values.

The test results of Johansen trace and max-eigen value tests are reported in Table 4.2. According to the table, both tests only reject the null hypothesis of no cointegrating vectors. In other words, the test results accept that there is at least one cointegrating relationship between nominal exchange rate and the monetary variables, such as money supply, income and interest rate. The identified cointegrating relationship can be interpreted as a long-term relationship among these variables. It supports the fact that the monetary approach is a reasonable explanation of exchange rate behavior during the sample period.

\section{Table 4.2 : Johansen Test for Cointegration Relations}

\begin{tabular}{|c|c|c|c|c|c|}
\hline \multirow[b]{2}{*}{$\mathbf{H}_{0}$} & \multirow[b]{2}{*}{$\mathbf{H}_{1}$} & \multicolumn{2}{|c|}{ Test Statistics } & \multicolumn{2}{|c|}{$5 \%$ critical Values } \\
\hline & & Trace & Max-Eigenvalue & Trace & Max-Eigenvalue \\
\hline$r=0$ & $r>1$ & 157.17 & 70.47 & 125.62 & 46.23 \\
\hline$r \leq 1$ & $r>2$ & 86.71 & 31.87 & 95.75 & 40.08 \\
\hline$r \leq 2$ & $r>3$ & 54.83 & 21.64 & 69.82 & 33.88 \\
\hline$r \leq 3$ & $r>4$ & 33.19 & 16.80 & 47.86 & 27.58 \\
\hline$r \leq 4$ & $r>5$ & 16.40 & 9.84 & 29.80 & 21.13 \\
\hline$r \leq 5$ & $r>6$ & 6.56 & 6.55 & 15.49 & 14.26 \\
\hline$r \leq 6$ & $r=7$ & 0.01 & 0.01 & 3.84 & 3.84 \\
\hline
\end{tabular}

Source : Author's Estimates 
Since all variables, except interest rates, are specified in logs the normalized equation denotes implied long-term elasticities. According to the equation, coefficients of US industrial production and US interest rates are not only very small but are also statistically insignificant. Coefficients of Sri Lankan interest and US money supply are significant at the $95 \%$ confidence level, while Sri Lankan money supply and industrial production are significant at the $90 \%$ confidence level. Sri Lankan industrial production, Sri Lankan interest rate and US interest rate have reported correct signs as expected theoretically. However, the result shows incorrect signs for money supply both in Sri Lanka and the US and US industrial production. Since central bank intervention is included as an exogenous variable, its sign and significance was checked with VEC output. Central bank intervention indicates net purchases of foreign exchange by the central bank. Therefore, the higher the purchases from the central bank the higher the demand for foreign currency, which is expected to depreciate the domestic currency. However, the empirical finding was contrary to the this expectation. The coefficient was not only small with wrong sign, but also was not statistically significant. Similarly, the dummy variable was also not significant.

Since both the exogenous variables are found to be statistically insignificant, they are dropped from the original model and cointegration equation and VEC were recalculated. New The new specification indicates that a lag level of 3, maximises the AIC criterion and eliminates serial correlation from the model. The new estimation confirms the presence of 2 cointegrating vectors among the variables, according to both max-eigen value and trace statistics. The re-estimated long-term cointegrating equation is as follows.

$$
\begin{aligned}
& \text { Inexr }_{t}=-1.96+0.13 \text { slmoneyy }_{t}-0.83 \text { slind }_{\text {- }} \text { pro }_{t}+0.017 \text { slint }_{t} \\
& \begin{array}{lll}
(-0.68) & (5.19) \quad(-8.03)
\end{array} \\
& +{\text { 0.94 } \text { usmoneyy }_{t}+\text { 0.344usind-pro }}_{t}-0.017 \text { usint } t \\
& (-2.92) \quad(-2.68)
\end{aligned}
$$

The new specification is superior to the old specification in many ways. The re-estimated cointegration equation reports relatively more statistically significant variables with correct signs and the values of coefficients are also improved. All Sri Lankan variables now report correct signs, though money supply was statistically insignificant. Among the US related variables, money supply has reported the incorrect sign. Several other studies have reported similar mixed findings regarding the signs of the monetary fundamentals [see Liew et al. (2009), Islam and Hasan (2006) and Abas and Yusof (2009)]. 
In addition to the long-term relationship, short-term dynamics of the models could be analysed based of on the VEC output shown in Table 2A of the Appendix. Accordingly, the error correction term is negative, as expected, and statistically significant. The significance of the lagged error-correction term implies a long-term causality from all variables in the monetary model towards the nominal exchange rate. A coefficient of -0.115 indicates that around $11.5 \%$ of disequilibrium in the nominal exchange rate in the short-term is corrected monthly. To be more specific, it takes less than a year to correct short-term disequilibrium and to restore long-term equilibrium of nominal exchange rate.

Existence of a short-term relationship between exchange rate and a few variables of the monetary model is evident from the outcome of the error correction model. SL industrial production with 1 and 2 lags, US money supply with 3 lags and US interest rate with 2 lags are significant at the 95\% confidence level, whereas SL money supply with 2 lags is significant at the $90 \%$ confidence level. This indicates that there is short-term causality from these variables to the nominal exchange rate.

Table A3 in the Appendix summarizes Granger causal relationship among the variables in the VEC model with 3 lags. VEC Granger Causality/ Block Exogeneity Wald test result shows some evidence of single directional causality running from macro variables to the exchange rate. Sri Lanka industrial production and US interest rate reject the null hypothesis of no causality running from these variables to exchange rate at the $10 \%$ and $5 \%$ significance levels, respectively. Similarly, exchange rate Granger causes US industrial production index. Thus, the Granger causality test provides some further evidence on the causation between the exchange rate and monetary variables, though it is not very strong.

\subsection{Testing for Monetary Restrictions}

Test result of monetary restrictions based on theLikelihood Ratio test (LR test) has been reported in Table 4.3. Findings of this test are mixed. Hypotheses $\mathrm{H}_{1}, \mathrm{H}_{2}$ and $\mathrm{H}_{3}$ are rejected at the $1 \%$ significance level, while $H_{4}$ is rejected at the $5 \%$ significance level. Rejection of $H_{1}$ and $H_{2}$ implies that neither domestic money nor foreign money proportionally influence nominal exchange rate. In economic terms, there is non-neutrality of money. Similarly, rejection of $H_{3}$ proves that domestic and foreign money supply do not have the same impact on the exchange rate that is operating in the opposite direction. Rejection of $\mathrm{H}_{4}$ indicates inequality of income elasticities in home country and foreign. However, non rejection of $H_{5}$ gives evidence to the fact that interest semi-elasticities are similar in home and foreign. In other words, changes in interest rates in home and foreign influences exchange rate by the same proportion but in opposite directions. These findings are not much different from the findings of a few other studies on emerging countries 
[see Islam and Hasan (2006) and Abas and Yusof (2009)]. These mixed findings indicate that the proposed relationship between exchange rate and variables of monetary model are not simple and direct empirically as assumed in the restricted flexible price monetary model. These findings also suggest that the restricted version of the monetary model that assume equality of coefficients of home and foreign may fail due to the rejection of these monetary restrictions.

\section{Table 4.3 : Johansen Test for Cointegration Relations}

\begin{tabular}{lcc}
\hline Null Hypothesis & Chi-Square & Probability \\
\hline$H_{1}: \beta_{1}=1$ & 7.14 & 0.008 \\
$H_{2}: \beta_{2}=-1$ & 9.02 & 0.003 \\
$H_{3}: \beta_{1}=-\beta_{2}$ & 10.56 & 0.001 \\
$H_{4}: \beta_{3}=-\beta_{4}$ & 4.59 & 0.03 \\
$H_{5}: \beta_{5}=-\beta_{6}$ & 0.01 & 0.933 \\
\hline
\end{tabular}

\subsection{Testing for Exclusion Restrictions}

The test result of the exclusion restriction is presented in Table 4.4. This test is carried out to check whether any of the variables of the monetary model can be excluded from the cointegrating vector. This is done using the LR test on the null hypothesis of the coefficient of the selected variable being zero. The null hypothesis of Sri Lankan money has been accepted, while the null hypotheses of other variables have been rejected. It indicates that Sri Lankan money could be excluded from forming cointegrating relations. Though this finding is contrary to the findings of several other studies, it confirms the long-term cointegration equation that reported the insignificance of Sri Lankan money supply.

Table 4.4 : Testing for Exclusion Restrictions

\begin{tabular}{ccc}
\hline Null Hypothesis & Chi-Square & Probability \\
\hline$H_{6}: \beta_{1}=0$ & 0.24 & 0.63 \\
$H_{7}: \beta_{2}=0$ & 7.58 & 0.00 \\
$H_{8}: \beta_{3}=0$ & 16.17 & 0.00 \\
$H_{9}: \beta_{4}=0$ & 3.85 & 0.05 \\
$H_{10}: \beta_{5}=0$ & 3.47 & 0.00 \\
$H_{11}: \beta_{6}=0$ & 5.31 & 0.02 \\
\hline
\end{tabular}

Source: Author's Estimates 


\section{Summary}

\subsection{Conclusion}

In this paper, the empirical validity of the flexible price model has been studied for Sri Lanka, in order to determine whether US dollar - Sri Lankan exchange rate movements are in line with the changes in monetary fundamentals. Nominal exchange rate, money supply, income and interest rate in both countries and central bank intervention in the Sri Lankan foreign exchange market have been chosen as key variables of the model. A sample period of ten years from 2001:1 - 2011:3 was considered for the study. The long-term cointegrating relationship and short-term dynamics have been studied by employing Johansen multivariate cointegration analysis and VEC. Also, the empirical validity of assumptions imposed on the restricted flexible price monetary model has been tested using LR test. This part summarizes major findings of this research.

Given that all variables are integrated of the same order, the Johansen cointegration test was carried out including central bank intervention and a dummy to capture the impact of the recent financial crisis on US industrial production as exogenous variables. The unique cointegrating vector was identified at the chosen lag of 2 , both by trace statistics and max-eigen value. The application of this model revealed that even though in general central bank intervention is deemed to be important in exchange rate determination, in Sri Lanka, it is not statistically significant. The same finding was reported for the dummy variable. Therefore in order to improve the model, these two insignificant variables were dropped from the model and the cointegrating equation was re-calculated.

For the revised model, 2 cointegrating equations were identified, both by trace statistics and max-eigen value at the appropriate lag of 3. This finding provides evidence of a long run relationship between exchange rate and monetary fundamentals. The long-term cointegrating equation of the revised model was far better than the initial model in terms of significance of the variables and the signs of the coefficients. All the variables, other than Sri Lankan money supply, are statistically significant at the 95\% confidence level. Insignificance of the Sri Lankan money supply is contrary to theory as well as empirical findings.

All Sri Lankan variables have reported correct signs for the coefficients, as expected by theory. Accordingly, a rise in Sri Lankan money, depreciates US dollar - Sri Lankan rupee exchange rate, while an increase in Sri Lankan income appreciates the exchange rate. Similar to the impact of money supply, a rise in Sri Lankan interest rate has a positive relationship with exchange rate, expressed in terms of Sri Lankan rupee per US dollar. Among the US related variables, variables other than money supply have 
reported correct signs. This kind of mixed findings in the directions has been reported in many other similar studies.

Outcome of VEC reports a negative and significant error correction term. Accordingly, around $11.5 \%$ of the disequilibrium is corrected monthly and long-term equilibrium is restored within a year. In other words, disequilibrium in exchange rate is adjusted to revert back to monetary fundamentals within a reasonable time. The high speed of adjustment implies the existence of fewer barriers to the adjustment process. This could also be interpreted as less intervention and turbulence in the exchange rate market that deviate the exchange rate behavior from economic fundamentals.

Though the causality test using VEC Granger Causality/ Block Exogeneity Wald test confirmed the presence of some causality, the overall finding of this test is not satisfactory. Single directional causality was found from Sri Lankan industrial production to exchange rate and US interest rate to exchange rate. Similarly, exchange rate Granger cause US industrial production index.

The test on commonly imposed assumptions of reduced form flexible price monetary model rejects the proportionality assumption of exchange rate and money supply. It denotes that changes in money supply in home and foreign do not affect the nominal exchange rate proportionally, so that money is non-neutral. The test of monetary restriction also rejects equal and opposite effects of money differential and income differential on exchange rate. The empirical findings being contrary to theoretical specifications could be due to the problems associated with the PPP relationship on which the model was built and/ or the existences of price stickiness and wage rigidities. However, the assumption of equal interest semi elasticity has been accepted. This signifies the influence of interest rate changes that result from monetary policy changes in both countries, on exchange rate. The rejection of most of these monetary restrictions of restricted form confirms the validity of the chosen unrestricted monetary model in explaining the long-term nominal exchange rate for Sri Lanka.

The result of the test of exclusion restrictions, that checks whether any of these fundamental variables can be excluded from the cointegrating vector, confirms the findings of the VEC. That is, only Sri Lankan money can be excluded from the model and all the other variables are statistically significant. This finding is, however, puzzling. The statistically insignificant nature of the relationship between exchange rate and money is somewhat a strange finding. The robustness of the finding to the choice of monetary aggregate has also been tested using $\mathrm{M}_{2}$ money supply that excludes deposits held by off-shore banking units. This estimate also produced a similar finding. So the findings are robust to the choice of monetary aggregates. 
It is worth discussing further about the possible reason for the puzzling, statistically insignificant nature of the relationship between domestic money supply and exchange rate. This could be attributed to the validity of assumptions underlined in the monetary model of exchange rate, such as PPP, uncovered interest parity, stable money demand, exogeneity of money and income to exchange rate. Empirical evidence suggest the existence of a stable money demand function in Sri Lanka [see Dharmaratne (2004) and Jegajeevan (2009)]. However, the validity of exogeneity of money supply in the current context of monetary policy in a small country like Sri Lanka is questionable. Many authors in the past challenged this assumption and suggested that money supply is, rather, determined endogenously with other macroeconomic fundamentals. Testing the validity of such assumption is beyond the scope of this study. The validity of PPP in the Sri Lankan context was studied by Wickremasinghe (2004) and adequate supportive evidences was not found to prove its validity. It is also important to keep in mind that many authors, who found evidence against the monetary model attributed the short time span of floating exchange rate data as the possible reason for the failure of this model. Groen (2000) highlighted the fact that a relatively short time span reduces the power of tests on unit root and cointegration. He further suggests the use of a panel data set to circumvent this problem. Another possible reason is the use of current period data of economic fundamentals in predicting current period exchange rate. The current period money supply, for instance, may not hold any leading information in predicting current period exchange rate movements. Rather, expectations about future money supplies, income levels and interest rate could possibly hold valuable information about exchange rate movements. Last, but not least, the explanation is associated with the sample period selected for this study. A considerable part of the sample includes financial crisis period and recovery periods. Money supplies in both countries have been increased as a part of expansionary monetary policy adopted by the respective central banks, as a response to the great financial crisis of 2008-2009. The improper findings related to money supplies and exchange rate could reflect the breakdown of the relationship found among the macroeconomic fundamentals and exchange rate in normal economic conditions.

Overall, the findings of this study did not provide adequate evidence to support the empirical validity of the flexible price monetary model as a long-term explanation of the US dollar - Sri Lankan rupee exchange rate. Although a cointegrating relationship between variables of the monetary model and exchange rate was found, the key variables of the model such as domestic money supply and foreign money supply have shown inaccurate findings. Domestic money supply was statistically insignificant and foreign money supply has reported with a wrong sign of causation. Therefore, based on the empirical evidence found in this research it is hard to accept the empirical validity of the flexible price monetary model of exchange rate in the selected sample period for Sri Lanka. However, the 
monetary model cannot be rejected entirely and future research with a few modifications and extensions to the model is warranted, before drawing any firm conclusion.

\subsection{Limitations and Extensions}

The key limitation of this study is the short sample period and frequency of data. Sri Lanka entered into the floating exchange rate regime only in 2001. This limits the appropriate sample only to ten year. Generally, studies on exchange rate were based on quarterly data. Data on quarterly frequency was not considered in this research due to inadequate observations. Further, due to unavailability of real income data (GDP) on monthly frequency the industrial production index has been considered a proxy for real income. However, both in Sri Lanka and the US the industrial production index is not a key economic indicator, though it has been widely used by researchers as a proxy for real income. The findings would have been more precise if GDP data had been included. Also, the short sample period limits the feasibility of extending the analysis to include forecasting exchange rate behavior based on the chosen model and evaluating its performance with that of random walk. Exchange rate movements in considerable periods covered in the sample were much influenced by the recent financial crisis and resulting changes in economic fundamentals. It is reasonable to expect a more accurate and influential outcomes from counterfactual analysis in the absence of such an event.

There is future potential for research in this area by studying this model based on a sticky price version, because the findings of this study could be due to the presence of price stickiness in the economy. Also, extending this study to a forward-looking monetary model might give supporting evidence that expectations of macroeconomic fundamentals have leading information on the movements of exchange rate in the long-run. Several other studies with this forward-looking version of this model have found evidence in favour of this model (e.g., Groen, 2000). It is recommended for future research to improve the model to capture market expectations on future fundamentals, such as inflation expectations, growth expectations. In addition, the model could be extended to widen the sample period and frequency to verify whether more accurate findings are feasible. The forecasting performance of the models could be evaluated when the sample is extended to a reasonable length, since these fundamental based models work well in the medium and long-term. 


\section{References}

Abas, K. H., and Z. Yusof, (2009), "Exchange Rate and Monetary Fundamental: Evidence from Malaysia and Japan", Conference Proceedings, International Conference on Business and Information 2009. URL: < bai2009.org/file/Papers/1357.doc> (accessed on $15 / 07 / 2011)$.

Bilson J. F. O. (1978), “The Monetary Approach to the Exchange Rate: Some Empirical Evidence," IMF Staff Paper 25, International Monetary Fund, Washington DC.

Chin, L. M.Azali, B. Zulkornain, and M. B. Yusoff, (2007), "The monetary model of exchange rate: evidence from the Philippines", Applied Economics Letters, Vol. 14, pp. 993-997.

Choudhry, T. and P. Lawler (1997), "The Monetary Model of Exchange Rates: Evidence from the Canadian Float of the 1950s," Journal of Macroeconomics, Vol.19, No.2, pp.349-362.

Civcir, I. (2003), "The Monetary Models of the Turkish Lira/Dollar Exchange Rate: Long Run Relationships, Short Run Dynamics and Forecasting”, Journal of Eastern European Economics, Vol.41, No.6, pp. 43-69.

Dornbusch, R. (1976),“Expectations and Exchange Rate Dynamics”, Journal of Political Economy, Vol.84, pp.1161-1176.

Dharmaratne, W.R.A. (2004) Demand for Money in Sri Lanka during the Post Liberalization Period, Staff Studies - Central Bank of Sri Lanka, 34 (1 \&2):1-12.

Dua, P. and R. Ranjan, (2011), "Modeling and Forecasting the Indian Re/US Dollar Exchange Rate," Working Paper 197, Centre for Development Economics, Delhi School of Economics, India.

Engle, C., N.C. Nelson, and K.D. West, (2007), "Exchange Rate Models are Not as Bad as You Think”, NBER Macroeconomics Annual, Vol. 22, University of Chicago press.

Frenkel, J. A. (1976), "A Monetary Approach to the Exchange Rate: Doctrinal Aspects and Empirical Evidence," Scandinavian Journal of Economics, 78, pp.200-224.

Groen, J. J. J. (2000), “The monetary Exchnage Rate Model as a Long-run Phenomenon,” Journal of International Economics, Vol.52, pp. 299-319.

Groen, J. J. J. (2002), "Cointegration and the Monetary Exchange Rate Model Revisited," Oxford Bulletin of Economics and Statistics, Vol.64, pp. 361-380. 
Hooper, P. and J. Morton (1982), "Fluctuations in the Dollar: A Model of Nominal and Real Exchange Rate Determination," Journal of International Money and Finance, Vol.1, pp.39-56.

Islam, M.F. and M.S. Hasan, (2006), "The Monetary Model of the Dollar- Yen Exchange Rate Determination: A Cointegration approach", International Journal of Business and Economics, Vol. 5, No. 2, pp 129-145.

Jegajeevan, S. (2009), “An Examination of Stability of Demand for Money in Sri Lanka: Implications for Monetary Policy", Conference Paper, International Conference on Business Management - 2009, University of Sri Jayewardenepura, Sri Lanka.

Johansen, S. (1995), "Likelihood-based Inference in Cointegrated Vector Autoregressive Models", Oxford University Press, London.

Lam, L., L. Fung and I.W. Yu, (2008), "Comparing Forecast Performance of Exchange Rate Models," Working Paper 08, Hong Kong Monetary Authority, Hong Kong.

Liew, V.K., A.Z. Baharumshah, and C.H. Puah (2009), "Monetary Model of Exchange Rate for Thailand: Long-run Relationship and Monetary Restrictions", Global Economic Review, Vol. 38, No.4, pp. 385-395.

MacDonald, R. and M. P. Taylor, (1991), “The Monetary Approach to the Exchange Rate: Long-Run Relationships and Coefficients Restrictions," Economics Letters, Vol.37, No.2, pp. 179-185.

Mark N.C. (1995), "Exchange Rate and Fundamentals: Evidence of Long Horizon Predictability," American Economic Review, Vol.85, pp. 201-18.

Meese, R. A. and K. Rogoff, (1983), "Empirical Exchange Rate Models of the Seventies: Do They Fit Out-of-Sample?" Journal of International Economics, Vol. 14, pp. 3-24.

Meredith, G. (2003), "Medium-Term Exchange Rate Forecasting: What Can We Expect?", IMF Working Paper 21, International Monetary Fund, Washington DC.

Moosa, I.A. (2000), "Exchange Rate Forecasting: Techniques and Applications", 1st Edition, St. Matin's Press, New York.

Neely, C.J. \& L. Sarno (2002), "How Well Do Monetary Fundamentals Forecast Exchange Rates?”, Federal Reserve Bank of St.Louis Review, Vol. 84, pp. 51-74

Rosenberg, M.R. (2003),"Exchange Rate Determination- Models and Strategies for Exchange rate Forecasting", 1st Edition, McGraw-Hill, New York. 
Sarno, L. and G. Valente, (2008), "Exchange Rates and Fundamentals: Footloose or Evolving Relationship?", CEPR Discussion Paper 6638, Centre for Economic Policy Research, United Kingdom.

Schroder, M. and R. Dornau, (1999), "What's on Their Mind: Do Exchange Rate Forecasters Stick to Theoretical Models?", ZEW Discussion Paper 08, Centre for European Economic Research, Mannheim.

Wickremasinghe, G.B. (2004). "Purchasing Power Parity Hypothesis in Developing Economies: Some Empirical Evidence from Sri Lanka”, Econometric Society 2004, Australasian Meetings 236, Econometric Society. 


\section{Appendix}

\section{Table A1 : Data Definition and Source}

\begin{tabular}{|l|l|l|}
\hline Variable & \multicolumn{1}{|c|}{ Definition } & \multicolumn{1}{|c|}{ Source } \\
\hline Inexr & $\begin{array}{l}\text { Month-end nominal US dollar - Sri Lankan rupee } \\
\text { exchange rate, expressed in rupee per one dollar. } \\
\text { (in log) }\end{array}$ & $\begin{array}{l}\text { Database of Central Bank of } \\
\text { Sri Lanka }\end{array}$ \\
\hline slmoney & $\begin{array}{l}\text { Seasonally adjusted } \mathrm{M}_{2 \mathrm{~b}} \text { money supply in log. } \\
\mathrm{M}_{2 \mathrm{~b}} \text { is the sum of currency held by the public and } \\
\text { all deposits held by the public with commercial } \\
\text { banks (both in domestic banking units and } \\
\text { off-shore banking units) }\end{array}$ & $\begin{array}{l}\text { Database of Central Bank of } \\
\text { Sri Lanka }\end{array}$ \\
\hline slind-pro & $\begin{array}{l}\text { Seasonally adjusted industrial production index in } \\
\text { log. (1997=100) }\end{array}$ & $\begin{array}{l}\text { Database of Central Bank of } \\
\text { Sri Lanka }\end{array}$ \\
\hline slint & $\begin{array}{l}\text { Month-end call money market rate } \\
\text { Central bank interventions in foreign exchange } \\
\text { market. It is the net purchase in foreign exchange } \\
\text { market shown in US dollar million. }\end{array}$ & $\begin{array}{l}\text { Database of Central Bank of } \\
\text { Sri Lanka }\end{array}$ \\
\hline cbint & $\begin{array}{l}\text { Seasonally adjusted } \mathrm{M}_{2} \text { money supply in log. } \mathrm{M}_{2} \\
\text { includes } \mathrm{M}_{1}, \text { money market mutual funds, savings } \\
\text { and small time deposits. }\end{array}$ & $\begin{array}{l}\text { Statistical release of Federal } \\
\text { Reserve Bank }\end{array}$ \\
\hline usmonk of \\
\hline usind-pro & $\begin{array}{l}\text { Seasonally adjusted industrial production index in } \\
\text { log. (2000=100) }\end{array}$ & $\begin{array}{l}\text { International Financial } \\
\text { Statistics, IMF }\end{array}$ \\
\hline usint & $\begin{array}{l}\text { Month-end money market rate } \\
\text { International Financial } \\
\text { Statistics, IMF }\end{array}$ \\
\hline
\end{tabular}


Table A2 : Parameter Estimates of Error Correction Models

\begin{tabular}{|c|c|c|c|c|c|c|c|}
\hline & $\mathrm{D}[\mathrm{LN}$ & D[SLMONEY) & PR0) & D[SLINT) & $\mathrm{D}[\mathrm{USI}$ & D[USIND_PR0) & D[USINT) \\
\hline intEq1 & $\begin{array}{r}-0.115177 \\
{[-2.31019]}\end{array}$ & $\begin{array}{r}0.051505 \\
{[1.99022]}\end{array}$ & $\begin{array}{r}-0.049481 \\
{[-0.42993]}\end{array}$ & $\begin{array}{l}15.45017 \\
{[2.15504]}\end{array}$ & $\begin{array}{c}0.001554 \\
{[0.06030]}\end{array}$ & $\begin{array}{r}0.238927 \\
{[3.82699]}\end{array}$ & $\begin{array}{r}1.820541 \\
{[3.33278]}\end{array}$ \\
\hline $\mathrm{D}[\operatorname{LNEXR}(-1)]$ & $\begin{array}{c}0.09333 \\
{[0.91201]}\end{array}$ & $\begin{array}{r}0.056112 \\
{[1.05633]}\end{array}$ & $\begin{array}{r}0.009626 \\
{[0.04075]}\end{array}$ & $\begin{array}{c}5.252079 \\
{[0.35690]}\end{array}$ & $\begin{array}{r}-0.002317 \\
{[-0.04380]}\end{array}$ & $\begin{array}{r}-0.347576 \\
{[-2.71233]}\end{array}$ & $\begin{array}{r}0.414012 \\
{[0.36925]}\end{array}$ \\
\hline $\mathrm{D}[\operatorname{LNEXR}(-2)]$ & $\begin{array}{r}0.060349 \\
{[0.58797]}\end{array}$ & $\begin{array}{r}-0.060625 \\
{[-1.13788]}\end{array}$ & $\begin{array}{r}-0.120998 \\
{[-0.51066]}\end{array}$ & $\begin{array}{r}-3.529382 \\
{[-0.23912]}\end{array}$ & $\begin{array}{r}-0.012034 \\
{[-0.22681]}\end{array}$ & $\begin{array}{r}-0.168015 \\
{[-1.30720]}\end{array}$ & $\begin{array}{r}1.060987 \\
{[0.94344]}\end{array}$ \\
\hline $\mathrm{D}[\operatorname{LNEXR}(-3)]$ & $\begin{array}{r}0.080287 \\
{[0.83604]}\end{array}$ & $\begin{array}{r}0.000425 \\
{[0.00852]}\end{array}$ & $\begin{array}{r}-0.230576 \\
{[-1.04009]}\end{array}$ & $\begin{array}{r}3.808847 \\
{[0.27581]}\end{array}$ & $\begin{array}{r}0.009394 \\
{[0.18924]}\end{array}$ & $\begin{array}{r}-0.127976 \\
{[-1.06420]}\end{array}$ & $\begin{array}{r}1.776839 \\
{[1.68871]}\end{array}$ \\
\hline D[SLMONEY(-1)] & $\begin{array}{r}0.226113 \\
{[1.13435]}\end{array}$ & $\begin{array}{r}-0.094946 \\
{[-0.91762]}\end{array}$ & $\begin{array}{r}0.408277 \\
{[0.88726]}\end{array}$ & $\begin{array}{l}20.14082 \\
{[0.70265]}\end{array}$ & $\begin{array}{r}-0.047233 \\
{[-0.45839]}\end{array}$ & $\begin{array}{r}-0.075978 \\
{[-0.30438]}\end{array}$ & $\begin{array}{r}-0.323415 \\
{[-0.14808]}\end{array}$ \\
\hline D[SLMONEY(-2)] & $\begin{array}{c}-0.34948 \\
{[-1.76497]}\end{array}$ & $\begin{array}{r}0.081581 \\
{[0.79372]}\end{array}$ & $\begin{array}{c}0.398734 \\
{[0.87231]}\end{array}$ & $\begin{array}{l}-60.97869 \\
{[-2.14157]}\end{array}$ & $\begin{array}{c}-0.003712 \\
{[-0.03626]}\end{array}$ & $\begin{array}{r}0.064415 \\
{[0.25979]}\end{array}$ & $\begin{array}{r}-0.140112 \\
{[-0.06458]}\end{array}$ \\
\hline D[SLMONEY(-3)] & $\begin{array}{c}0.024634 \\
{[0.12248]}\end{array}$ & $\begin{array}{c}0.256952 \\
{[2.46130]}\end{array}$ & $\begin{array}{c}0.050703 \\
{[0.10921]}\end{array}$ & $\begin{array}{l}-17.63426 \\
{[-0.60974]}\end{array}$ & $\begin{array}{r}-0.027411 \\
{[-0.26366]}\end{array}$ & $\begin{array}{c}-0.18032 \\
{[-0.71598]}\end{array}$ & $\begin{array}{r}-1.021588 \\
{[-0.46360]}\end{array}$ \\
\hline D[SLIND_PRO(-1)] & $\begin{array}{r}0.111625 \\
{[1.98535]}\end{array}$ & $\begin{array}{r}-0.036208 \\
{[-1.24064]}\end{array}$ & $\begin{array}{r}-0.480566 \\
{[-3.70258]}\end{array}$ & $\begin{array}{r}-3.239379 \\
{[-0.40066]}\end{array}$ & $\begin{array}{c}-0.05269 \\
{[-1.81293]}\end{array}$ & $\begin{array}{r}-0.038651 \\
{[-0.54897]}\end{array}$ & $\begin{array}{r}0.093515 \\
{[0.15180]}\end{array}$ \\
\hline D[SLIND_PRO(-2)] & $\begin{array}{r}0.133875 \\
{[2.52637]}\end{array}$ & $\begin{array}{r}-0.008864 \\
{[-0.32224]}\end{array}$ & $\begin{array}{r}-0.211673 \\
{[-1.73036]}\end{array}$ & $\begin{array}{c}3.292004 \\
{[0.43201]}\end{array}$ & $\begin{array}{c}-0.048254 \\
{[-1.76159]}\end{array}$ & $\begin{array}{r}-0.097623 \\
{[-1.47115]}\end{array}$ & $\begin{array}{r}0.318547 \\
{[0.54865]}\end{array}$ \\
\hline D[SLIND_PRO(-3)] & $\begin{array}{r}0.061561 \\
{[1.44472]}\end{array}$ & $\begin{array}{r}-0.022218 \\
{[-1.00452]}\end{array}$ & $\begin{array}{c}-0.05176 \\
{[-0.52620]}\end{array}$ & $\begin{array}{c}1.560109 \\
{[0.25461]}\end{array}$ & $\begin{array}{r}-0.001949 \\
{[-0.08848]}\end{array}$ & $\begin{array}{r}-0.040073 \\
{[-0.75101]}\end{array}$ & $\begin{array}{c}-0.20423 \\
{[-0.43744]}\end{array}$ \\
\hline D[SLINT(-1)] & $\begin{array}{c}-0.00138 \\
{[-1.49863]}\end{array}$ & $\begin{array}{r}9.79 \mathrm{E}-05 \\
{[0.20490]}\end{array}$ & $\begin{array}{r}0.002156 \\
{[1.01423]}\end{array}$ & $\begin{array}{r}-0.401166 \\
{[-3.02970]}\end{array}$ & $\begin{array}{r}0.000129 \\
{[0.27149]}\end{array}$ & $\begin{array}{r}0.002115 \\
{[1.83389]}\end{array}$ & $\begin{array}{c}0.01327 \\
{[1.31531]}\end{array}$ \\
\hline D[SLINT(-2)] & $\begin{array}{r}-0.000916 \\
{[-1.14320]}\end{array}$ & $\begin{array}{r}-0.000363 \\
{[-0.87411]}\end{array}$ & $\begin{array}{r}0.002881 \\
{[1.55826]}\end{array}$ & $\begin{array}{r}-0.292317 \\
{[-2.53791]}\end{array}$ & $\begin{array}{r}0.000419 \\
{[1.01216]}\end{array}$ & $\begin{array}{r}-0.000295 \\
{[-0.29421]}\end{array}$ & $\begin{array}{r}-0.027293 \\
{[-3.10994]}\end{array}$ \\
\hline D[SLINT(-3)] & $\begin{array}{r}-0.000882 \\
{[-1.21070]}\end{array}$ & $\begin{array}{r}-0.000311 \\
{[-0.82203]}\end{array}$ & $\begin{array}{r}0.003381 \\
{[2.00945]}\end{array}$ & $\begin{array}{c}0.11203 \\
{[1.06888]}\end{array}$ & $\begin{array}{r}0.000879 \\
{[2.33391]}\end{array}$ & $\begin{array}{c}0.000316 \\
{[0.34574]}\end{array}$ & $\begin{array}{r}-0.008935 \\
{[-1.11883]}\end{array}$ \\
\hline D[USMONE & $\begin{array}{r}0.258726 \\
{[1.34857]}\end{array}$ & $\begin{array}{r}0.028746 \\
{[0.28866]}\end{array}$ & $\begin{array}{r}-0.452301 \\
{[-1.02126]}\end{array}$ & $\begin{array}{l}-14.7035 \\
{[-0.53296]}\end{array}$ & $\begin{array}{r}0.001078 \\
{[0.01087]}\end{array}$ & $\begin{array}{r}-1.273129 \\
{[-5.29929]}\end{array}$ & $\begin{array}{r}-0.777241 \\
{[-0.36976]}\end{array}$ \\
\hline D[USMONEY(-2)] & $\begin{array}{r}0.069765 \\
{[0.35300]}\end{array}$ & $\begin{array}{c}-0.00295 \\
{[-0.02876]}\end{array}$ & $\begin{array}{r}-0.156304 \\
{[-0.34260]}\end{array}$ & $\begin{array}{l}-24.8127 \\
{[-0.87308]}\end{array}$ & $\begin{array}{r}-0.365351 \\
{[-3.57621]}\end{array}$ & $\begin{array}{r}0.357499 \\
{[1.44453]}\end{array}$ & $\begin{array}{r}0.504817 \\
{[0.23313]}\end{array}$ \\
\hline D[USMONEY(-3)] & $\begin{array}{c}0.433204 \\
{[2.03376]}\end{array}$ & $\begin{array}{c}0.155128 \\
{[1.40301]}\end{array}$ & $\begin{array}{r}-0.405625 \\
{[-0.82491]}\end{array}$ & $\begin{array}{l}-15.59948 \\
{[-0.50928]}\end{array}$ & $\begin{array}{r}0.103275 \\
{[0.93794]}\end{array}$ & $\begin{array}{r}-0.438615 \\
{[-1.64438]}\end{array}$ & $\begin{array}{r}-0.442705 \\
{[-0.18969]}\end{array}$ \\
\hline D[USIND_PRO(-1) & $\begin{array}{r}-0.020062 \\
{[-0.26106]}\end{array}$ & $\begin{array}{r}-0.037308 \\
{[-0.93526]}\end{array}$ & $\begin{array}{r}-0.067151 \\
{[-0.37852]}\end{array}$ & $\begin{array}{c}0.008083 \\
{[0.00073]}\end{array}$ & $\begin{array}{r}-0.067828 \\
{[-1.70743]}\end{array}$ & $\begin{array}{r}-0.542106 \\
{[-5.63326]}\end{array}$ & $\begin{array}{r}0.621862 \\
{[0.73855]}\end{array}$ \\
\hline D[USIND_PRO(-2)] & $\begin{array}{r}0.137051 \\
{[1.53028]}\end{array}$ & $\begin{array}{r}0.020283 \\
{[0.43631]}\end{array}$ & $\begin{array}{r}-0.286993 \\
{[-1.38815]}\end{array}$ & $\begin{array}{l}-11.17505 \\
{[-0.86772]}\end{array}$ & $\begin{array}{r}-0.076327 \\
{[-1.64870]}\end{array}$ & $\begin{array}{r}-0.265638 \\
{[-2.36860]}\end{array}$ & $\begin{array}{r}0.287623 \\
{[0.29312]}\end{array}$ \\
\hline D[USIND_PRO(-3)] & $\begin{array}{r}0.043645 \\
{[0.57920]}\end{array}$ & $\begin{array}{r}0.008585 \\
{[0.21949]}\end{array}$ & $\begin{array}{r}0.253227 \\
{[1.45571]}\end{array}$ & $\begin{array}{r}1.421731 \\
{[0.13120]}\end{array}$ & $\begin{array}{r}0.002422 \\
{[0.06217]}\end{array}$ & $\begin{array}{r}0.011723 \\
{[0.12423]}\end{array}$ & $\begin{array}{r}0.087568 \\
{[0.10606]}\end{array}$ \\
\hline D[USINT(-1)] & $\begin{array}{r}-0.008731 \\
{[-0.89599]}\end{array}$ & $\begin{array}{r}0.003366 \\
{[0.66556]}\end{array}$ & $\begin{array}{r}0.038631 \\
{[1.71740]}\end{array}$ & $\begin{array}{r}-1.181042 \\
{[-0.84288]}\end{array}$ & $\begin{array}{r}-0.000495 \\
{[-0.09818]}\end{array}$ & $\begin{array}{r}-0.005209 \\
{[-0.42689]}\end{array}$ & $\begin{array}{r}0.465421 \\
{[4.35945]}\end{array}$ \\
\hline D[USINT(-2)] & $\begin{array}{r}0.023745 \\
{[2.41324]}\end{array}$ & $\begin{array}{r}-0.007515 \\
{[-1.47139]}\end{array}$ & $\begin{array}{r}-0.037364 \\
{[-1.64501]}\end{array}$ & $\begin{array}{r}1.144587 \\
{[0.80896]}\end{array}$ & $\begin{array}{r}-0.013165 \\
{[-2.58829]}\end{array}$ & $\begin{array}{r}-0.015852 \\
{[-1.28658]}\end{array}$ & $\begin{array}{r}-0.048999 \\
{[-0.45451]}\end{array}$ \\
\hline D[USINT(-3)] & $\begin{array}{r}0.013723 \\
{[1.45484]}\end{array}$ & $\begin{array}{r}-0.001232 \\
{[-0.25151]}\end{array}$ & $\begin{array}{r}0.002255 \\
{[0.10356]}\end{array}$ & $\begin{array}{r}-0.674184 \\
{[-0.49702]}\end{array}$ & $\begin{array}{r}0.007976 \\
{[1.63575]}\end{array}$ & $\begin{array}{r}-0.021221 \\
{[-1.79647]}\end{array}$ & $\begin{array}{c}-0.074012 \\
{[-0.71611]}\end{array}$ \\
\hline $\mathrm{C}$ & $\begin{array}{r}-0.001551 \\
{[-0.31749]}\end{array}$ & $\begin{array}{c}0.008542 \\
{[3.36949]}\end{array}$ & $\begin{array}{c}0.003254 \\
{[0.28864]}\end{array}$ & $\begin{array}{c}0.752784 \\
{[1.07192]}\end{array}$ & $\begin{array}{r}0.007313 \\
{[2.89667]}\end{array}$ & $\begin{array}{r}0.009813 \\
{[1.60455]}\end{array}$ & $\begin{array}{r}-0.013635 \\
{[-0.25482]}\end{array}$ \\
\hline
\end{tabular}


Table A3 : Outcome of VEC Granger Causalty / Block Exogeneity Wald Test

\begin{tabular}{|c|c|c|c|}
\hline \multicolumn{2}{|c|}{ Dependent variable: $D(L N E X R)$} & \multicolumn{2}{|c|}{ Dependent variable: D(USMONEY) } \\
\hline Excluded & Prob. & Excluded & Prob. \\
\hline D(SLMONEY) & 0.1858 & $\mathrm{D}(\mathrm{LNEXR})$ & 0.9919 \\
\hline D(SLIND_PRO) & $\underline{0.0795}$ & D(SLMONEY) & 0.9593 \\
\hline $\mathrm{D}(\mathrm{SLINT})$ & 0.3971 & D(SLIND_PRO) & 0.1794 \\
\hline D(USMONEY) & 0.2013 & $\mathrm{D}(\mathrm{SLINT})$ & 0.1322 \\
\hline D(USIND_PRO) & 0.2290 & D(USIND_PRO) & 0.1470 \\
\hline$\underline{\mathrm{D}(\mathrm{USINT})}$ & $\underline{0.0147}$ & $\mathrm{D}(\mathrm{USINT})$ & 0.0245 \\
\hline \multicolumn{2}{|c|}{ Dependent variable: D(SLMONEY) } & \multicolumn{2}{|c|}{ Dependent variable: D(USIND_PRO) } \\
\hline Excluded & Prob. & Excluded & Prob. \\
\hline D(LNEXR) & 0.4683 & $\underline{\mathrm{D}(\mathrm{LNEXR})}$ & $\underline{0.0256}$ \\
\hline D(SLIND_PRO) & 0.4223 & D(SLMONEY) & 0.8626 \\
\hline D(SLINT) & 0.5921 & D(SLIND_PRO) & 0.5071 \\
\hline D(USMONEY) & 0.5671 & $\mathrm{D}(\mathrm{SLINT})$ & 0.0458 \\
\hline D(USIND_PRO) & 0.5530 & D(USMONEY) & 0.0000 \\
\hline D(USINT) & 0.4532 & $\mathrm{D}(\mathrm{USINT})$ & 0.0661 \\
\hline \multicolumn{2}{|c|}{ Dependent variable: D(SLIND_PRO) } & \multicolumn{2}{|c|}{ Dependent variable: D(USINT) } \\
\hline Excluded & Prob. & Excluded & Prob. \\
\hline D(LNEXR) & 0.7377 & D(LNEXR) & 0.3219 \\
\hline D(SLMONEY) & 0.6903 & D(SLMONEY) & 0.9687 \\
\hline D(SLINT) & 0.2227 & D(SLIND_PRO) & 0.7861 \\
\hline D(USMONEY) & 0.7180 & $\mathrm{D}(\mathrm{SLINT})$ & 0.0000 \\
\hline D(USIND_PRO) & 0.0081 & D(USMONEY) & 0.9757 \\
\hline D(USINT) & 0.2338 & D(USIND_PRO) & 0.9066 \\
\hline \multicolumn{4}{|c|}{ Dependent variable: $D(S L I N T)$} \\
\hline Excluded & Prob. & & \\
\hline D(LNEXR) & 0.9655 & & \\
\hline D(SLMONEY) & 0.1349 & & \\
\hline D(SLIND_PRO) & 0.8361 & & \\
\hline D(USMONEY) & 0.7801 & & \\
\hline D(USIND_PRO) & 0.5779 & & \\
\hline D(USINT) & 0.7914 & & \\
\hline
\end{tabular}

